\title{
FIELD TECHNIQUES FOR EXPERIMENTAL STRESS ANALYSIS IN ARGTIG SEA ICE
}

\author{
By G. V. B. Cochran \\ (Biomechanics Research Unit, Helen Hayes Hospital, West Haverstraw, New York Io993, \\ U.S.A.)
}

\begin{abstract}
Increasing interest is being directed toward studies involving measurement of strain and strain-rates in sea and glacier ice. A number of techniques for obtaining these data over gauge lengths ranging from $\mathrm{I} \mathrm{m}$ to several kilometers have been reported, but there has been little experience with shorter lengths. Use of commercially available electrical resistance strain-gauges (length $5^{-20} \mathrm{~cm}$ ) intended for embedment in concrete offers a new approach in which multiple gauge, two- and three-dimensional arrays can be installed in ice with minimum effort and monitored with portable equipment. This report describes a pilot study designed to demonstrate the use of three types of electrical resistance strain gauges in sea ice under exposed field conditions. Results include detection of variations in strain fields related to tidal currents.

RÉsumé. Techniques de terrain pour une analyse experimentale des contraintes dans la glace de mer arctique. On apporte un intérêt grandissant aux études comportant des mesures de déformation et de vitesses de déformation dans le glace de mer et de glacier. Beaucoup de techniques pour obtenir ces données ont été décrites comprenant des longueurs de témoins de $\mathrm{I} \mathrm{m}$ à plusieurs $\mathrm{km}$, mais il y a eu peu d'essais avec des longueurs inférieures. L'utilisation de jauges de déformation par résistance électrique, commercialement disponibles (longueur $5^{-20 \mathrm{~cm}}$ ) conçues pour être noyées dans le béton, donne une nouvelle approche permettant d'installer dans la glace une gauge multiple à 2 ou 3 directions avec le minimum d'effort et un matériel portable. Cet article décrit une étude pilote imaginée pour montrer l'utilisation de trois modèles de jauges de déformation à résistance électriques dans la glace de mer avec des conditions extérieures difficiles. Les résultats comprennent la détection des variations dans le champ des déformations provoquées par les courants de marée.
\end{abstract}

Zusammenfassung. Feldtechniken zur experimentellen Spannungsanalyse in arktischem Meereis. Studien mit Messungen der Verformung und Verformungsrate in Meer- und Gletschereis finden wachsendes Interesse. Über mehrere Verfahren zu Gewinnung diese Daten mit Eichstrecken zwischen I $\mathrm{m}$ und einigem $\mathrm{km}$ wurde berichtet, doch liegen nur wenige Erfahrungen mit kürzeren Strecken vor. Mit handelsüblichen Geräten zur Verformungsmessung über den elektrischen Widerstand (Länge $5^{-20} \mathrm{~cm}$ ), die zum Einbau in Beton gedacht sind, eröffnet sich ein neuer Weg für mehrfache Eichung und zwei- oder dreidimensionale Anordnung im Eis bei kleinstem Aufwand und mit tragbarer Ausrüstung. Dieser Bericht beschreibt eine grundsätzliche Studie zur Demonstration des Gebrauches dreier Typen von solchen Verformungsmessgeräten im Meereis unter schwierigen Feldbedingungen. Die Ergebnisse erstrecken sich auch auf die Erfassung von Schwankungen im Deformationsfeld infolge von Gezeitenströmungen.

\section{INTRODUGTION}

Convenient field techniques for measurement of mechanical strain in ice offer the potential of applying traditional methods of experimental stress analysis to research on diverse aspects of behavior of sea and glacier ice. This report describes a pilot study involving three different types of electrical resistance strain gauges frozen into sea ice in the Canadian Arctic.

In the past, a number of methods for determination of mechanical strain in ice have been described. Hibler and others (1973) discussed applications of aerial photographic, tellurometer, and laser techniques to "mesoscale" measurements with gauge lengths in the 5-10 km range. On glaciers, traditional surface-marker techniques have long been the standard for measurement of surface strain over shorter gauge lengths in the order of magnitude of $100 \mathrm{~m}$, as demonstrated by Nye (1959); on the same scale, a laser interferometer has been employed more recently by Holdsworth (1975). Vertical strains in bore holes in glaciers also have been measured using gauge lengths in the range of $\mathrm{I} m$ (Rogers and LaChapelle, I974; Paterson, 1976). Methods for measurement of surface strains over gauge lengths under $5 \mathrm{~m}$ were lacking until the reports of Warner and Cloud (1974), and Masterson and others (1979) on constantan wire (electrical resistance) gauges, as well as the work of Goodman and others (1975), Evans and others (1978), and Squire (1978) who adapted Cambridge (geophysical-type) wire strainmeters to ice. All these techniques employed gauge lengths in the range of $2-5 \mathrm{~m}$, and proved to be effective although all tend to be rather laborious to install. Even shorter gauge 
lengths were utilized by Hirayama and others (1974, p. 54) under laboratory conditions, when standard SR-4, electrical resistance gauges were frozen in ice after providing suitable waterproofing and a sanded backing to improve adhesion.

For any investigation, it is essential that the gauge length selected is consistent with the phenomenon to be measured. For example, Colbeck and Evans (197I) pointed out that there is a lower limit of gauge length for effective measurements pertaining to regional flow on glaciers. Also, for dynamic measurements, the ratio of gauge length to wave length is of extreme importance (Squire, 1978). For determination of stresses, strain data may be converted provided the 'modulus of elasticity and Poisson's ratio of ice under similar conditions are known or can be determined on site. The mechanical properties of sea ice have been reviewed by Schwarz and Weeks (1977).

Testing of commercial concrete embedment gauges in sea ice was the primary object of this study conducted during May 1978 near Grise Fiord, Northwest Territories, Canada (Ellesmere Island) and at a remote location by a tent camp on Makinson Inlet I $5 \mathrm{~km}$ to the north-east (lat. $77^{\circ} 12^{\prime}$ N., long. $80^{\circ} 4^{\prime}$ W.). Although little prior experience is available with measurements using the short length of these gauges, it is felt that the unusual convenience of the technique warrants consideration and development.

\section{INSTRUMENTATION AND PROCEDURES}

During this work, three types of gauge were tested: (I) BLH Electronics: EMBC $300-35$ Embedment Gauge (length $7.6 \mathrm{~cm}$; resistance $350 \Omega$; gauge factor 2.0). The gauge is cast within a polycarbonate plastic paddle $(25 \mathrm{~cm} \times 2.5 \mathrm{~cm} \times 0.3 \mathrm{~cm})$ with a corrugated surface and an integral, waterproofed lead connection (Fig. I). (2) Alitech: CG-I29 Embedment Gauge. This commercial gauge consists of a semi-rigid, strain-sensitive wire (length $10 \mathrm{~cm}$;

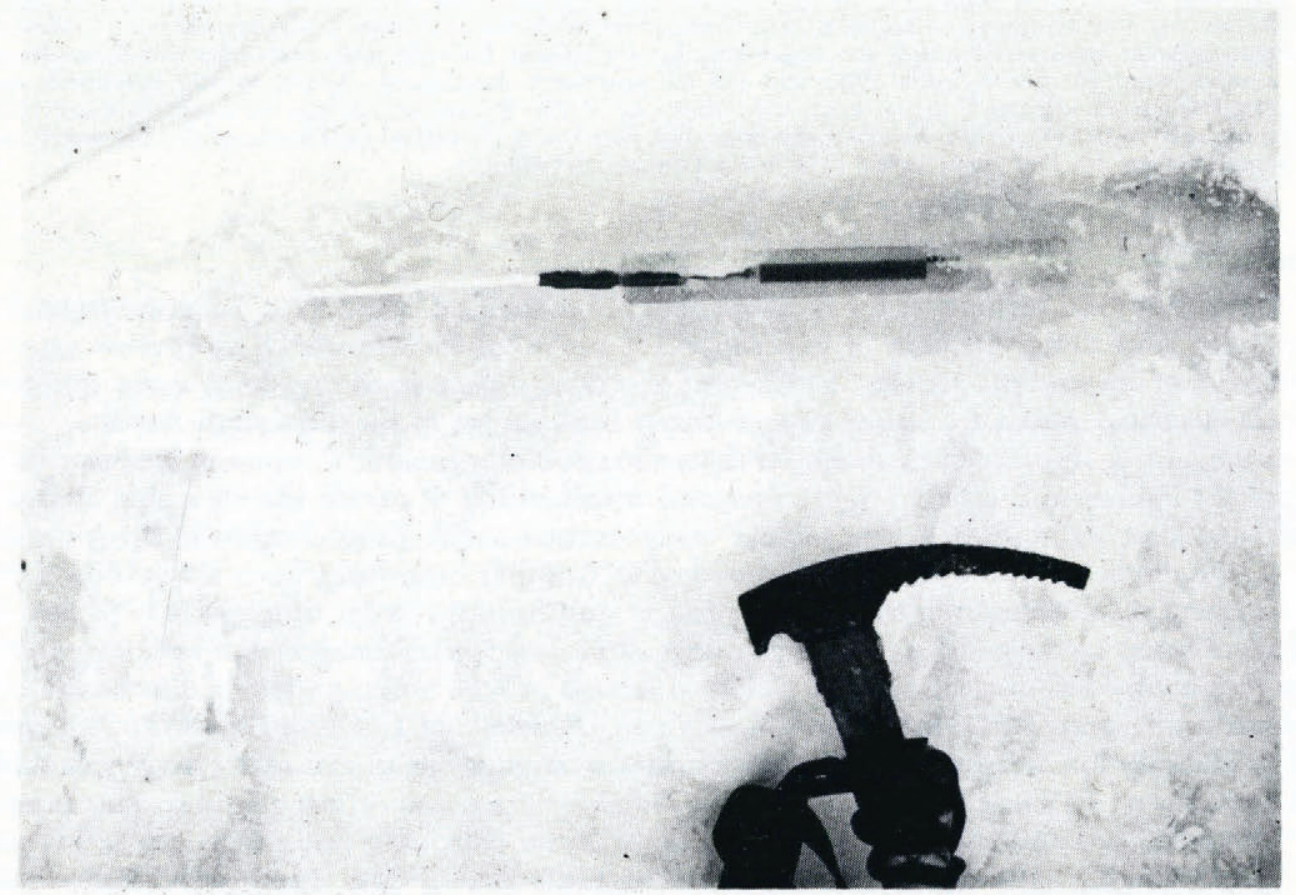

Fig. 1 . View of BLH gauges during removal from ice at Makinson Inlet. The actual $7.6 \mathrm{~cm}$ gauge is plainly visible within the plastic paddle. 
resistance $120 \Omega$; gauge factor 2.0) with fixation grids at each end; it is available in gauge lengths of $5^{-20} \mathrm{~cm}$ with an integral waterproofed lead. Both the BLH and Alitech gauges are designed primarily for embedment in asphalt or concrete and are self temperature compensated to exhibit minimal apparent strain with temperature changes in the latter material. (3) Constantan wire gauge (Warner and Cloud, I 974). This non-commercial unit consists of a "Teflon"-coated constantan wire $0.0127 \mathrm{~cm}$ in diameter which provides a $120 \Omega$ resistance over a $3 \mathrm{~m}$ length with a gauge factor of 2 . The wire is installed by stretching between two anchors, but according to the authors, the anchors may loosen without causing significant alteration in strain readings after the wire has been frozen in place. Preliminary trials with this device were conducted on a glacier near Grise Fiord, Northwest Territories by this investigator in 1976 .

For the present study, all gauges were frozen into the surface plane of sea ice at a depth of $4 \mathrm{~cm}$. The BLH and Alitech gauges were laid on the bottom of suitable channels or trenches cut with an alpine hammer. For the constantan wire gauges, $3.5 \mathrm{~m}$ lengths of the wire were prepared in advance by soldering to suitable leads and waterproofing the connections. A $4 \mathrm{~m}$ channel was cut in the ice and an ice piton placed near either end. To install the gauge, a $3 \mathrm{~m}$ segment of the wire was marked off and one end anchored by winding around a wooden dowel in which narrow saw cuts had been made. Firm locking was provided by taiping the dowel and wire, then the dowel was attached to the piton with a waxed harness cord. A similar operation was carried out at the other end where the gauge was pre-tensioned to a strain of o.oor to facilitate recording changes which involve compression as well as tension. The pre-tensioning was done with care because the overall elastic behavior of this wire had been observed to extend only to a strain of 0.025 . Finally, all trenches were filled with fresh water and allowed to freeze; the free ends of the constantan wire and their sealed lead connections extended just above the ice to insure against waterproofing problems. After freezing, all installation areas were covered by $10 \mathrm{~cm}$ of snow to improve insulation against air-temperature variations.

For measurements, each gauge was connected to a portable, "Strainsert", eight-channel, static strain indicator, in a quarter-bridge configuration using a three-wire lead system. Resolution of this indicator system is $\mathrm{I} \times \mathrm{IO}^{-6}$ with an accuracy of $\pm 5 \times 10^{-6}$ strain. Gauge excitation provided by this unit is a $2 \mathrm{~V}$ square wave at $500 \mathrm{~Hz}$; gauge factor was set at 2.0 in accordance with specifications of the units. A special dummy resistor circuit was utilized to balance the slightly higher resistance of constantan wire gauges; for critical measurements, prior calibration of these gauges would be essential. Temperature in the ice adjacent to the gauges was monitored by two Micro Measurements, $50 \Omega$, resistance temperature sensors connected to the same strain indicator utilizing a Micro Measurements LST-10oC- $350 \mathrm{~B}$ network for signal conditioning. Each gauge circuit was balanced prior to embedment; readings then were taken at intervals once freezing was complete. Following measurements at the first location, the commercial gauges were removed for re-use by careful chopping with an alpine hammer.

\section{Measurement sites and gauge arrays}

The first site was in the sea ice of Jones Sound approximately $200 \mathrm{~m}$ from shore and directly in front of Grise Fiord settlement. Gauges were installed adjacent to the aircraft parking area, where the ice was said to be $\mathrm{I} .3 \mathrm{~m}$ thick. Fifteen sets of readings were taken at $4 \mathrm{~h}$ or greater intervals over a total period of $6 \mathrm{o} \mathrm{h}$. At this site, three Alitech and three BLH gauges were installed in standard rectangular rosette patterns, and two constantan wire gauges in a $90^{\circ}$ pattern. The reference limb of each rosette was parallel to shore.

The second measurement site, at Makinson Inlet, was $10 \mathrm{~m}$ from shore in a narrow band of smooth ice lying between ice pushed on the shore and a miniature pressure ridge. Here, 
only the BLH embedment gauges were employed. Again, three were installed in a rectangular rosette pattern, but with the $\epsilon_{1}$ or reference gauge placed perpendicular to shore as shown diagrammatically in Figure 2. Thirty sets of readings were taken at intervals over a $72 \mathrm{~h}$ period with hourly readings obtained during comparable afternoon/evening hours. Data were processed to define the surface strain field by determination of principal strains, maximum shear strain, and orientation of maximum shear strain, utilizing standard equations (Dally and Riley, 1965, chap. 16, p. 426-29).

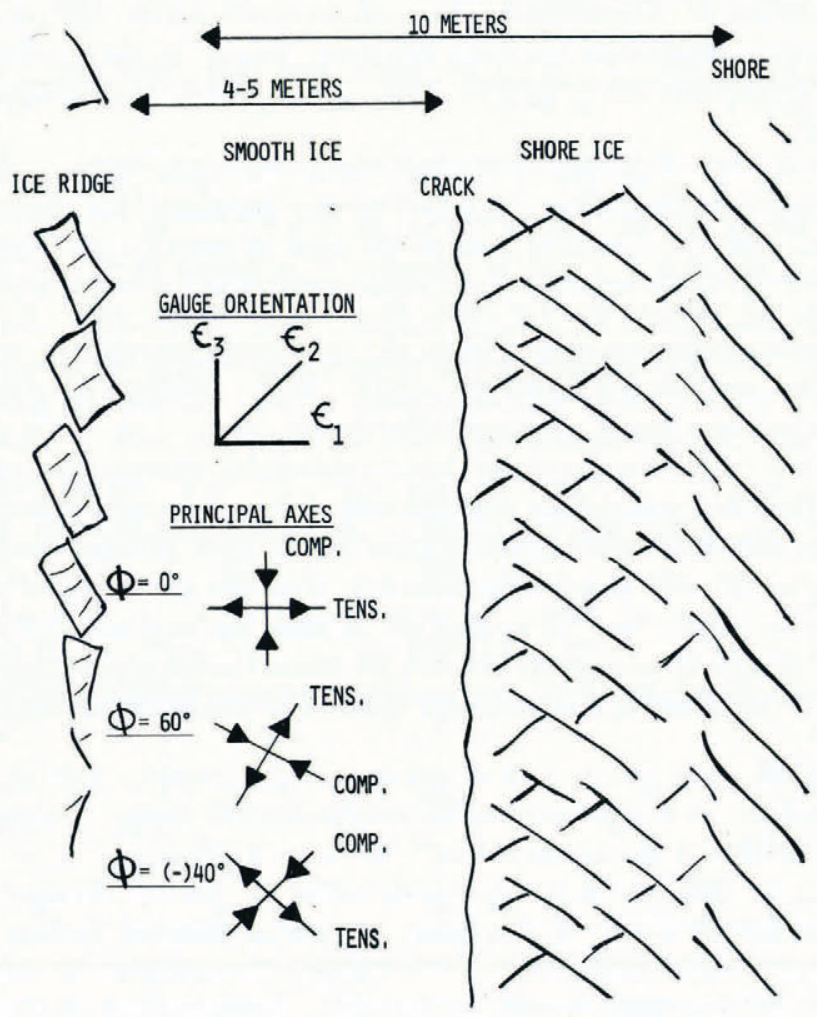

Fig. 2. Diagram of installation site at Makinson Inlet showing gauge orientation in relationship to shore. Also indicated are axes of principal strains for varying values of $\phi$ (angle between reference gauge, $\epsilon_{1}$ and axis of maximum tension strain).

\section{Results}

At Grise Fiord, the BLH gauges gave the most consistent results with strains measured by each gauge in the rosette varying in a qualitatively similar pattern in the range of $+100 \times 10^{-6}$ (tension) to $(-) 300 \times 10^{-6}$ (compression). Readings tended to be more erratic from the other types of gauges although an unexplained peak in the readings from all gauges did occur at one point in time. Of interest in these limited experiments was the observation that none of the gauges failed to register significant change when DC-3 or Twin Otter aircraft were parked or removed approximately $25 \mathrm{~m}$ away or when a bulldozer was driven to within $3 \mathrm{~m}$.

At the Makinson Inlet site, readings from the three BLH gauges during the afternoon and evening of one day are shown in Figure 3 . On this occasion, strains ranging from $+120 \times 10^{-6}$ (tension) to $(-) 360 \times \mathrm{ro}^{-6}$ (compression) were recorded with strain-rates at times approaching $\mathrm{IO}^{-4} \mathrm{~h}^{-1}$. Results of the analysis of the rosette data from the three successive days are displayed 
in Figure $4(a, b, c)$. Examination of these plots reveals an apparent recurring pattern each day with respect to magnitude of principal tension and compression strains and shear strain, as well as to orientation of maximum strain as indicated by angle $\phi$ and nominal strain-rates. Also, there was a tendency for the axes of the principal strains to reverse alignment with respect to the shore between the hours near noon and midnight (Fig. I; Fig. 4c). A I-2 cm crack existed in the ice parallel to the measurement area, but no adequate means of measurement were available to define apparent changes in the width of this crack that occurred during the measurement period.

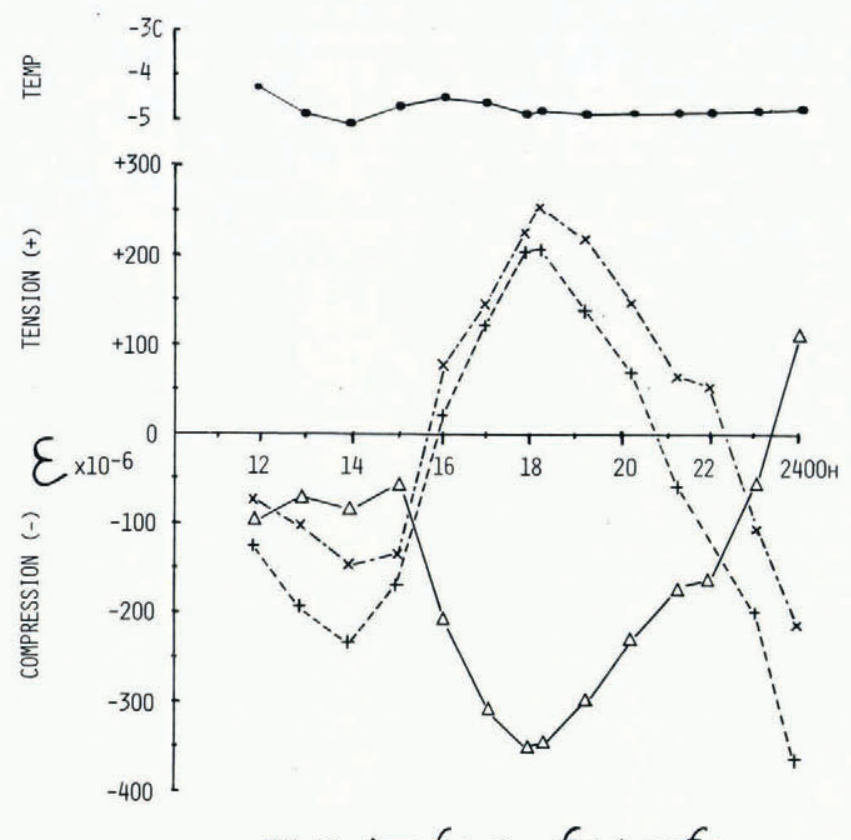

$\operatorname{MAY} 22: \Delta-\epsilon_{1 \times-\cdot-} \epsilon_{2}+---\epsilon_{3}$

Fig. 3. Raw strain data from BLH gauge rosette at Makinson Inlet on 22 May 1978. $\epsilon_{\mathrm{I}}$ is the reference gauge, placed perpendicular to shore (see Fig. I). Temperature measured in ice adjacent to the gauges is plotted above.

\section{Discussion AND conclusions}

Although the data are limited, the daily recurrence and approximate $12 \mathrm{~h}$ interval of the cycle in the data from Makinson Inlet are suggestive of strain variations caused by tidal currents generating forces on ice adjacent to shore. Unfortunately, the actual hours of high and low tide were unknown as was the thickness of the ice at this location. Time and conditions did not permit a comparative set of measurements further from shore where tidal currents might have been reduced.

At Grise Fiord, the test site was in a more open off-shore area and strain variations were probably of a different nature although the measurements were made at longer intervals, so patterns could not be compared. The lack of effect seen when heavy equipment was brought into proximity of the gauges is not surprising in view of the thickness of the ice and the mechanics of small-area loads on floating ice sheets as described by Nevel (1977). In all cases, it should be recognized that the measurements represented strain variations about an unknown basal state of loading, rather than the total state of strain in the ice. 


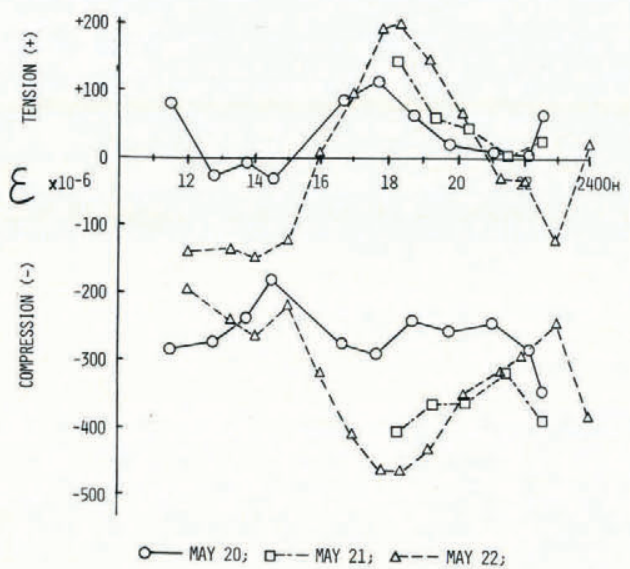

$a$

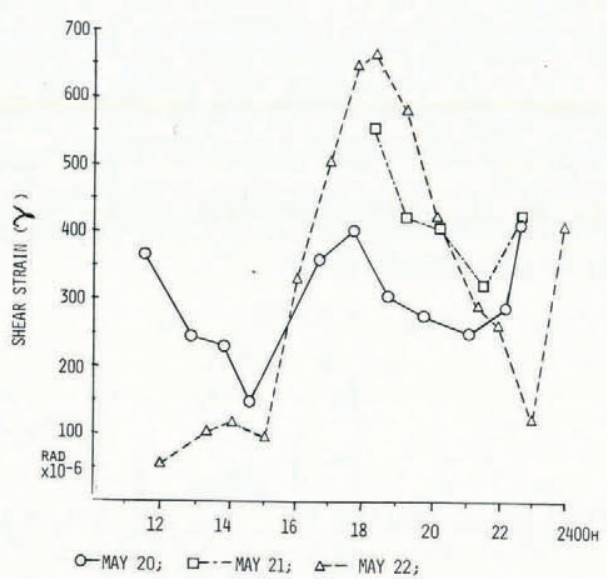

$b$

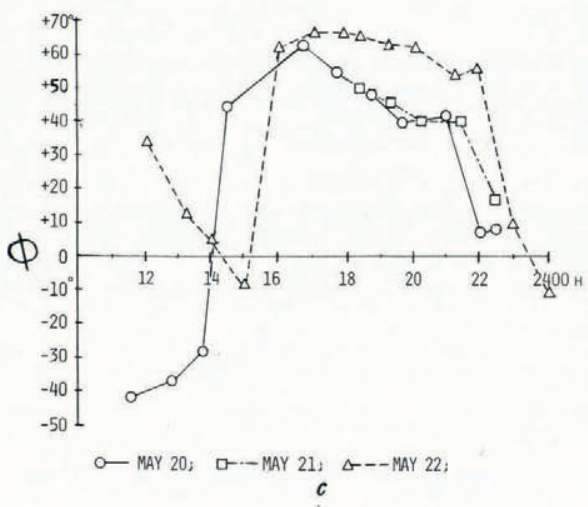

Fig. 4. (a) Principal strains (maximum tension and compression) plotted for comparison on three successive days, during the period $11.00-24.00 \mathrm{~h}$. (b) Maximum shear strain plotted for comparison during the same period. (c) Angle $\phi$ plotted for comparison during the same period.

Errors in these results could arise from several sources. In calculation of principal strains from rosette data, small misalignments of gauge axes can produce serious errors under certain conditions. To reduce this possibility, use of a Delta or T-Delta rosette pattern would be preferred as these arrangements tolerate the greatest margin of misalignment error when directions of principal strains are completely unknown.

Measurement errors could arise from temperature variations as well as long-term drift. The BLH gauges are constructed to produce minimal apparent strain due to temperature when embedded in concrete. Tested in air or in small billets of fresh-water ice, these gauges show an apparent strain of approximately $50 \times 10^{-6} \mathrm{deg}^{-1}$ over the range of $+20^{\circ} \mathrm{C}$ to $-20^{\circ} \mathrm{C}$. To correct for these variations, data from an unstressed gauge buried in a waterproof tube near the measurement array may be employed. While this was not done during this study, variations in temperature monitored in ice adjacent to gauges at Makinson Inlet were minimal, so it is unlikely that significant errors were introduced (Fig. 2). Another potential source of error is poor bonding between the gauge and ice. This condition is difficult to 
quantify in the field, but at both Grise Fiord and Makinson Inlet, intimate adhesion of ice to the heavily corrugated surface of the plastic paddles was apparent during gauge removal.

Finally, there are problems related to gauge length and material. Aside from the necessity of selecting a gauge length suitable for the variable to be measured, the problem of errors introduced by small cracks or other defects in ice must be raised since a strain gauge records the mean strain over its length. In these experiments, no prior defects could be detected in the gauge area by visual inspection. Also, it seems doubtful that the low-modulus plastic encapsulant of the gauge introduced significant stiffening. In general, it may be of interest to note that the many problems associated with embedment of gauges in sea ice are similar to those encountered previously by the author in development of techniques for implantation of strain gauges on skeletal bone in animals, within the equally difficult environment of living tissue (Cochran, 1972).

Of the gauges tested, the BLH units proved to be the most practical for difficult field applications although data were inadequate for detailed comparisons with the Alimed or constantan-wire gauges. Further work is needed to determine the relationship between measurements made with single or multiple (in line) $5^{-10} \mathrm{~cm}$ gauges in comparison with $3 \mathrm{~m}$ constantan wires. Improvements in the manufacturing process to further adapt the BLH gauges for use in ice seem entirely within the realm of current technology. For example, gauges with longer active gauge lengths could be manufactured, and adjustments made in the elastic modulus of the polycarbonate carrier to avoid stress concentrations or stiffening. Also, closer matching of gauges to temperature coefficients of ice should be possible. Regarding the constantan-wire gauges, advances in control of technical problems associated with their use have been reported in detail by Masterson and others (1978).

\section{FUTURE APPLICATIONS}

Application of standard techniques of experimental stress analysis to study of mechanical events in glacier and sea ice is now becoming practical because multiple strain-gauge arrays can be installed with ease and monitored under difficult field conditions utilizing light-weight, inexpensive equipment. A battery-operated measurement system including a 20-channel digital strain indicator, single-channel continuous recorder and all associated gauges can weigh as little as $10 \mathrm{~kg}$, and cost under $\$ 4000$ (U.S.). Using such a system, studies of material properties, flow characteristics, ice forces, load-bearing behavior, and other phenomena in glaciers and sea ice become more practical. Also, three-dimensional arrays consisting of six to nine gauges embedded near the surface and in small bore holes could be employed to facilitate a complete description of the six components of the strain tensor at a point; techniques for three-dimensional strain-rosette studies were originated by Baker and Dove (1963) and have been updated by Rossetto and others (1974). To determine total strain in an ice structure, it could be feasible to cut out a block around an array of embedded gauges. As with any new technique, availability should create opportunities for specific applications to be developed.

\section{Acknowledgements}

The aid of Mr H. Schriebl and other members of the 1978 Ellesmere-Bowman Island Expedition in obtaining these measurements, and of Mr R. Derman in preparing equipment, is appreciated. Also, the author is indebted to the people of Grise Fiord, Northwest Territories for their assistance and permission to conduct this study, to the Government of the Northwest Territories for assignment of Scientific Research License No. 2286 and to the Explorers Club for their award of Flag No. I89. Dr D. J. Goodman kindly provided invaluable comments on an early draft of this report. 


\section{LIST OF SUPPLIERS}

Alitech, 19535 East Walnut Drive, City of Industry, California 91 744, U.S.A. BLH Electronics, 42 Fourth Avenue, Waltham, Massachusetts 02 I 54, U.S.A. Measurements Group, P.O. Box 27777, Raleigh, North Carolina 276I I, U.S.A.

Omega Engineering, Inc. (constantan wire), Box 4047, Springdale Station, Stamford, Connecticut o6907, U.S.A.

Strainsert Co., Union Hill Industrial Park, West Conshohocken, Pennsylvania 19428, U.S.A.

MS. received io April 1979

\section{REFERENCES}

Baker, W. C., and Dove, R. C. 1963 . Construction and evaluation of a three-dimensional strain rosette. Experimental Mechanics, Vol. 3, No. 9, p. $20 \mathrm{I}-06$.

Cochran, G. V. B. 1972. Implantation of strain gages on bone in vivo. Journal of Biomechanics, Vol. 5, No. I, p. 1 I 9-23.

Colbeck, S. C., and Evans, R. J. 1971. Small-scale strain measurements on a glacier surface. Fournal of Glaciology, Vol. 10, No. 59, p. 237-43.

Dally, J. W., and Riley, W. F. 1965. Experimental stress analysis. New York, McGraw-Hill Book Co., Inc.

Evans, K., and others. 1978. Recording wire strainmeters on the Barnes Ice Cap, Baffin Island, Canada, by K. Evans, D. J. Goodman, and G. [H.] Holdsworth. Journal of Glaciology, Vol. 20, No. 83, p. 409-23.

Goodman, D. J., and others. 1975. Wire strainmeters on ice, [by] D. J. Goodman, A. J. Allan, R. G. Bilham. Nature, Vol. 255, No. 5503, p. 45-46.

Hibler, W. D., III, and others. 1973. Mesoscale strain measurements on the Beaufort Sea pack ice (AIDJEX 1971), by W. D. Hibler III, W. F. Weeks, S. [F.] Ackley, A. Kovacs, and W. J. Campbell. Fournal of Glaciology, Vol. 12, No. 65, p. 187-206.

Hirayama, K., and others. 1974. An investigation of ice forces on vertical structures, by K. Hirayama, F. Schwarz, and H. C. Wu. Iowa City, Iowa Institute of Hydraulic Research, University of Iowa. (IIHR Report No. 158.)

Holdsworth, G. H. 1975. Measurement of small strain-rates over short time periods. Fournal of Glaciology, Vol. 14, No. 71, p. 317-24.

Masterson, D. M., and others. 1979. Strain measurements in floating ice platforms and their application to platform design, by D. M. Masterson, K. G. Anderson, A. G. Strandberg. Canadian Fournal of Civil Engineering, Vol. 6 , No. 3, p. $394-405$.

Nevel, D. E. 1977. Concentrated loads on a floating ice sheet. Journal of Glaciology, Vol. 19, No. 81, p. $237-45$.

Nye, J. F. 1959. A method of determining the strain-rate tensor at the surface of a glacier. Fournal of Glaciology, Vol. 3 , No. 25 , p. $409^{-1} 9$.

Paterson, W. S. B. 1976. Vertical strain-rate measurements in an Arctic ice cap and deductions from them. Fournal of Glaciology, Vol. 1 7, No. 75, p. 3-12.

Rogers, J. C., and LaChapelle, E. R. 1974. The measurement of vertical strain in glacier bore holes. Fournal of Glaciology, Vol. 13, No. 68, p. 315-19.

Rossetto, S., and others. I 975 . Three-dimensional strain rosettes: pattern selection and performance evaluation, by S. Rossetto, A. Bray, R. Levi. Experimental Mechanics, Vol. i 5, No. 10, p. 375-81.

Schwarz, J., and Weeks, W. F. 1977. Engineering properties of sea ice. Fournal of Glaciology, Vol. 10, No. 81, p. $499-531$.

Squire, V. A. 1978. An investigation into the use of strain rosettes for the measurement of propagating cyclic strains. Fournal of Glaciology, Vol. 20, No. 83, p. 425-31.

Warner, G., and Cloud, G. 1974. Measurement of surface strain rates in glaciers using embedded wire strain gages. Experimental Mechanics, Vol. 14, No. I, p. 24-28. 